\title{
Theory of Reasoned Action Implementation on Knowledge Sharing Process Between Alumni and College Students
}

\author{
Niffari Meirina BERNOVA ${ }^{1}$, Dwi Rosa INDAH ${ }^{2 *}$, Rahmat Izwan HEROZA ${ }^{3}$, Tri \\ Ayu RACHMADITA ${ }^{4}$, Annisa SEPTIANI ${ }^{5}$ and Rizki Dwi CAHYANI ${ }^{6}$
}

${ }^{1,2,3,4,5,6}$ Faculty of Computer Science, Universitas Sriwijaya, Indonesia

*Corresponding author : indah812@unsri.ac.id

\begin{abstract}
This study aims to identify user requirements based on the results of hypothesis to find out the features needed with the framework of Theory of Reasoned Action as the basic theory of reference to find out the factors someone's wants to share their knowledge. This study uses the quantitative method of Partial Least Square. The data was collected through questionnaires with a confidence level of $95 \%$. The selected respondents were 90 alumni of Information System 2014. The hypothesis testing was carried out with SmartPLS analytic instruments. The results of this study obtained 4 features that are needed by the user to generate intentions and attitudes to share knowledge. That four features namely; Share, Comments, Search Knowledge and Discussions Forum.
\end{abstract}

Keywords: Theory of Reasoned Action, user requirement, knowledge sharing

\section{INTRODUCTION}

Knowledge Management (KM) is the key to achieving success for an organization. Knowledge Management is also a power to keep the organization afloat. Knowledge needed needs to be shared so that knowledge is not lost. One of the benefits of knowledge management support is encouraging the learning process which has implications for increasing innovation support through new knowledge [1].

The spread of knowledge among fellow members of the organization can help members get easier to get new learning and make them more innovative. Sharing Knowledge is a unit of behavior that involves exchanging information or assistance for others. In organizations, especially in universities, knowledge sharing behavior is needed to increase the knowledge of each student.

This knowledge can be obtained through a sharing process between college students and alumni. Previously, some of college students faced obstacles and found a point of confusion in determining the topic of the final assignment. In addition, the experience of the alumni can help students to get a variety of information.

However, to share knowledge it takes a confidence from the individual to share his knowledge, because the most important part of $\mathrm{KM}$ is how to encourage individuals in organizations to share knowledge about what they know [2].

So that, based on the explanation above, with the development of a theory regarding knowledge management, especially about Knowledge Sharing Behavior, it can encourage individuals to share their knowledge. Through knowledge sharing, knowledge can be shared. In addition, knowledge sharing can facilitate individuals, especially students, to re-use and regenerate the knowledge that will be shared. To find out the perspective of individual behavior in terms of knowledge sharing, the framework of Theory of Reasoned Action (TRA) was chosen as a support. TRA suggests that individual behavior is determined by the intention or intention to behave (intention) and that will is a function of attitude (subjective) and norms (subjective norm) [3].

With the background as described above, research is carried out on the factors that influence knowledge sharing among students and alumni majoring in Information Systems Faculty of Computer Science Unsri. The final results of this study will also be obtained features that can support knowledge sharing activities in accordance with the analysis of the results of the hypothesis

\section{METHODOLOGY}

\section{The Proposed Model and Hypotheses}

In this study, the process of thinking framework was constructed into a research model adopted from the Theory of Reasoned Action (TRA). Theory of Reasoned Action (TRA) describes behavior that changes based on the results of behavioral intentions and behavioral intentions influenced by social norms and individual attitudes towards behavior [4].

Especially in the context of knowledge sharing, it is believed that knowledge sharing behavior can be influenced by beliefs, intentions, attitudes and subjective norms. The variables that will be used as statements on the questionnaire are obtained from the results of the questionnaire pilot analysis. The pilot questionnaire also includes some items that will be formulated to get the influence of knowledge sharing indicators. The data obtained is used to select reliable and valid items to be used in the final questionnaire. Following are the steps to make a pilot questionnaire. 
"What is the biggest influece that makes you want to share you knowledge?"

These items will be used as interview material to two student samples. Then, the results of the interview will be described and will be linked to the TRA framework indicator, so that the items will be obtained for the questionnaire to be distributed to 90 alumni.

Referring to the framework, one independent variable (X) is obtained, namely confidence and three dependent variables (Y), namely attitudes, subjective norms and intentions. Each of these variables is measured by each dimension, including:

Belief (X1) is measured by :

I feel that knowledge sharing is important (X11)

I believe that my friends influence me to share my knowledge (X12)

Attitude (Y1) is measured by :

I would like to share my knowledge if there is media available to use (Y11) I loved to search knowledge that my friends already shared

"Do you intend to share your knowledge?"

I feel so glad when my friends give appreciation to my knowledge (Y13)

I loved to share my knowledge if my friends share their knowledge too (Y14)

Subjective norm (Y2) is measured by:

I will share my knowledge if I get support from my friends (Y21)

I will join discussion forum if there is such an interesting topic (Y22) My friends and I share our knowledge oftenly to others (Y23)

Intention (Y3) is measured by :

I intend to share my knowledge (Y31)

I feel no doubt to share my knowledge (Y32)

I will share my knowledge if people asked (Y33)

The above statements will be distributed to the respondents in the form of questionnaires. The test results of each indicator were conducted using the Likert Scale method, while the calculation of the analysis was carried out using the Partial Least Square method with the help of SmartPLS applications. The following hypothesis is proposed in this study:

$\mathrm{H} 1$ : alleged influence of attitude towards intention $\mathrm{H} 2$ : alleged influence of belief towards attitude

$\mathrm{H} 3$ : alleged influence of subjective norm towards intention

Population and Samples

The type of data used in this study is primary data. Primary data is data collected through the results of the questionnaire where the questionnaire will be a statement relating to the implementation of the Theory of Reasoned Action. Primary data is obtained through the distribution of survey questionnaires to alumni of the Fasilkom Information System Unsri class of 2014 with the number of respondents as many as 90 alumni.

The researcher used descriptive and inferential analysis to analyze the results of questionnaire dissemination from respondents. Determination of the number of sampling in this study using a determination formula that has been developed by Slovin.

$$
\begin{aligned}
& n=\frac{N}{1+N \theta^{2}} \\
& \text { Explanation : } \\
& n=\text { number of samples (90 alumni) } \\
& \mathrm{N}=\text { population } \\
& \mathrm{e}=\text { level of fault }(5 \%)
\end{aligned}
$$

Results and Discussion Validity Test

When the survey has been carried out and the required data has been obtained, the statement that is feasible or not will be tested with the help of the SmartPLS program. The process that must be done is to sort the top priority and later it will be matched again. After the data is processed, it can be seen in the Outer Loading 3.1 image, showing from 12 questions on items X11, X12, Y11, Y12, Y13, Y14, Y21, Y22, Y23, Y31, Y32, Y33 there are 10 valid statements that can be used as references for features for the knowledge sharing system prototype and two deceased statements were obtained.

The X11 and Y13 variables must be reduced from the research model because they have an Outer Loading value of $<0.05$. The process of reducing the indicator has been done one by one 
Table 1. Outer Loading after being reduce

equentially starting from the indicator that has the smallest recommended value.

In addition, the value of the Outer model is done by looking at the value of Convergent Validity. This is measured based on the value of correlation with variables measured by the value of Loading Factor $>0.70$ is highly recommended [5], but for values $>0.50-0.60$ can still be tolerated as long as the model is still in development [6]. The following is attached to table 4.1 the Outer Loading value of the data after being reduced, so that all indicators used to measure the variables in this study are valid.

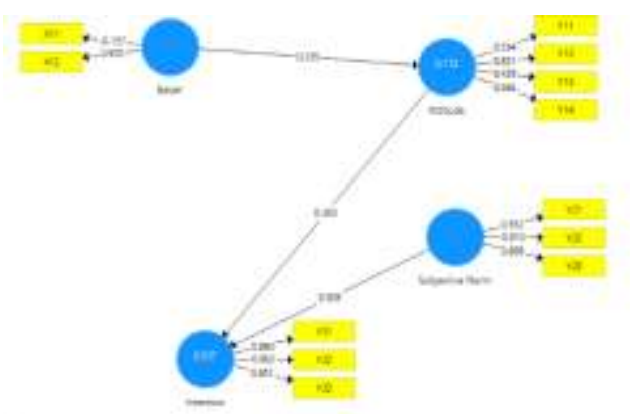

Figure 1 Path Coefficient Before Being Reduc

Table 2. Code, Indicator and Features of Belief

\begin{tabular}{|c|l|c|}
\hline Code & \multicolumn{1}{|c|}{ Indicator } & Features \\
\hline $\mathrm{X} 12$ & $\begin{array}{l}\text { I believe that my friends influence me to share my } \\
\text { knowledge }\end{array}$ & $\begin{array}{l}\text { Searching } \\
\text { knowledge }\end{array}$ \\
\hline
\end{tabular}

\section{Influence of attitude towards sharing knowledge behavior}

\section{Influence of belief towards sharing \\ knowledge behavior}

\begin{tabular}{|c|c|c|c|c|}
\hline Code & Attitude & Belief & $\begin{array}{c}\text { Subjective } \\
\text { Norm }\end{array}$ & Intention \\
\hline X12 & & 1.000 & & \\
\hline Y11 & 0,585 & & & \\
\hline Y12 & 0,872 & & & \\
\hline Y14 & 0,679 & & & \\
\hline Y21 & & & 0,552 & \\
\hline Y22 & & & 0,810 & \\
\hline Y23 & & & 0,869 & \\
\hline Y31 & & & & 0,861 \\
\hline Y32 & & & & 0,904 \\
\hline Y33 & & & & 0,649 \\
\hline
\end{tabular}

After obtaining results from indicators that have been reduced, the next step is to determine the features needed to support the knowledge sharing activities of the 10 questions.

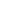


Table 3. Code, Indicator and Features of Attitude

\begin{tabular}{|c|l|c|}
\hline Code & \multicolumn{1}{|c|}{ Indicator } & Features \\
\hline Y11 & $\begin{array}{l}\text { I would like to share my knowledge if there is media } \\
\text { available to use }\end{array}$ & $\begin{array}{c}\text { Share } \\
\text { knowledge }\end{array}$ \\
\hline Y12 & $\begin{array}{l}\text { I loved to search knowledge that my friends already } \\
\text { shared }\end{array}$ & $\begin{array}{l}\text { Searching knowledge } \\
\text { their knowledge too }\end{array}$ \\
\hline Y14 & Timeline / dashboard \\
\hline
\end{tabular}

\section{Influence of subjective norm} towards sharing knowledge behavior

Table 4. Code, Indicator and Features of Subjective Norm

\begin{tabular}{|c|l|c|}
\hline Code & \multicolumn{1}{|c|}{ Indicator } & Features \\
\hline Y21 & $\begin{array}{l}\text { I will share my knowledge if I get support from my } \\
\text { Friends }\end{array}$ & Comment \\
\hline Y22 & $\begin{array}{l}\text { I will join discussion forum if there is such an } \\
\text { interesting topic }\end{array}$ & Discussion forum \\
\hline Y23 & $\begin{array}{l}\text { My friends and I share our knowledge oftenly to } \\
\text { others }\end{array}$ & Share knowledge \\
\hline
\end{tabular}

\section{Influence of subjective norm} towards sharing knowledge behavior

Table 5. Code, Indicator and Features of Intention

\begin{tabular}{|c|l|c|}
\hline Code & \multicolumn{1}{|c|}{ Indicator } & Features \\
\hline Y31 & I intend to share my knowledge & Share knowledge \\
\hline Y32 & I feel no doubt to share my knowledge & Share knowledge \\
\hline Y33 & I will share my knowledge if people asked & Discussion forum \\
\hline
\end{tabular}

\section{RELIABILITY TEST}

Data reliability test is measured by measuring the consistency and stability of the score (measurement scale). For data quality seen from composite reliability values generated from SmartPLS software from existing variables, namely;
Belief(X1), Attitude (Y1), Subjective norm (Y2), Intention (Y3). A good composite reliability value is $\rho c \geq 0.80$ and it can be said that the construct has high reliability and also Average Variance Extracted (AVE) $>0.50$.

The following are the results of reliability testing for all indicators examined in table 6 . The results of the table show that all research variables have been shown to be feasible gauges. In general, the variables studied from all statement items have a good level of reliability. 
Table 6. Reliability Test

\begin{tabular}{|c|c|c|}
\hline Variabel & $\begin{array}{c}\text { Composite } \\
\text { Reliability }\end{array}$ & $\begin{array}{c}\text { Average Variance } \\
\text { Extracted (AVE) }\end{array}$ \\
\hline Attitude & 0.761 & 0.521 \\
\hline Belief & 1.000 & 1.000 \\
\hline Intention & 0.851 & 0.659 \\
\hline Subjective \\
Norm
\end{tabular}

\section{STRUCTURAL MODEL MEASUREMENT TEST (INNER MODEL)}

Inner model testing is done to see the relationship between variables from the research model. The structural model is evaluated using R-Square (coefficient of determination) for the independent variable. The higher the R-Square value, the greater the ability of the independent variable to explain the dependent variable. The following are the results of the $\mathrm{R}$-square values listed in table 7 below

Table 7. R - Square

\begin{tabular}{|c|c|}
\hline & R - Square \\
\hline X1 & \\
\hline Y1 & 0,106 \\
\hline Y2 & \\
\hline Y3 & 0,531 \\
\hline
\end{tabular}

The intention variable (Intention) has the largest R-Square value, which is 0.531 , which means that the intention variable that can be explained by Attitude and subjective norms is $53.10 \%$ and the remaining $46.9 \%$ is determined by other factors outside the research.

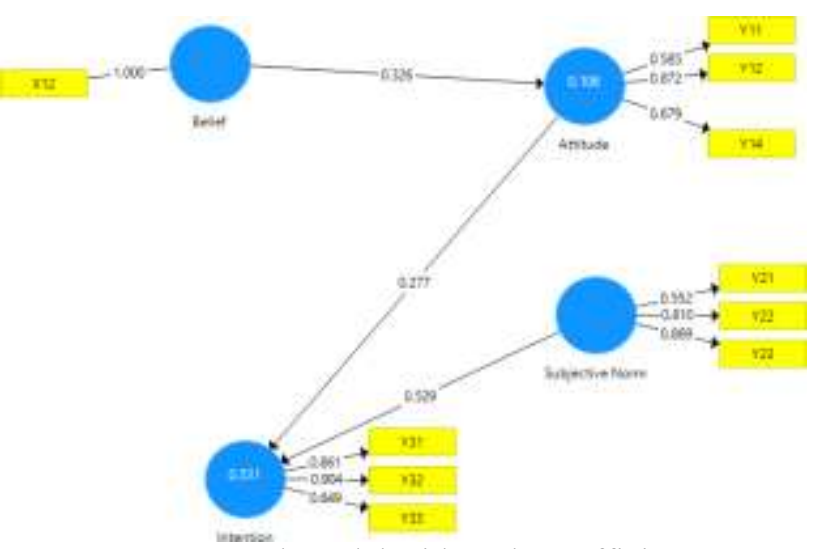

Figure 2 Structural Model with Path Coefficient

Based on the results of table calculations, the structural equations are as follows: $\mathrm{Y} 1=0,326 \mathrm{X} 1$

$\mathrm{Y} 3=0,277 \mathrm{Y} 1+0,529 \mathrm{Y} 2$ 
Table 8. Path Coeffisient

\begin{tabular}{|c|c|}
\hline Path & Coefficient \\
\hline Belief (X1) $\rightarrow$ Attitude (Y1) & 0,326 \\
\hline Attitude (Y1) $\rightarrow$ Intention (Y3) & 0,277 \\
\hline Subjective Norm (Y2) $\rightarrow$ Intention (Y3) & 0,529 \\
\hline
\end{tabular}

From the structural equationabove, it can be seen that from the factors that influence attitude (Y1) and the most influential is the trust variable (X1), while for the factors that influence intention (Y3), the most influential is the subjective norm (Y2).

\section{HYPOTHESIS TESTING}

Hypothesis testing is based on the values found in the analysis of structural models, the significance level of the path is obtained from the t-value, the standardized path coefficient value, the probability value $(\mathrm{P})$ used as a predictor is the significance of the relationship or influence between variables. The value limit of hypothesis testing is that the t-value of the factor (factor loadings) is greater than the critical value $(\geq 1.98)$. Table 9 will explain the details of the hypothesis.

First hypothesis: attitude influences intention, intention of $t$ statistic is $2,397 \geq 1,98$ and $p$ value $0,017>0,05$, it can be concluded that there is no significant influence on attitudes toward intention. The second hypothesis: belief influences attitudes, the results of the $t$ statistic are 4,532 $\geq 1,98$ and $p$ value $0,000<0,05$, it can be concluded that there is a significant influence between belief in attitude The third hypothesis: subjective norms influence the intention (intention), the result of $\mathrm{t}$ statistic is $4.966 \geq 1.98$ and $\mathrm{p}$ value $0,000<0.05$ can be concluded that there is a significant influence of subjective norms on intention.

Table 9. Hypothesis Test

\begin{tabular}{|l|l|l|}
\hline No & \multicolumn{1}{|c|}{ Hypothesis } & \multicolumn{1}{|c|}{ Result } \\
\hline H1 & alleged influence of attitude towards intention & rejected \\
\hline H2 & alleged influence of belief towards attitude & Accepted (significant) \\
\hline H3 & alleged influence of subjective norm towards intention & Accepted (significant) \\
\hline
\end{tabular}

\section{DIRECT AND INDIRECT EFFECT}

Analysis of Direct Effect and Indirect Effect and the purpose is to analyze the strength of influence between constructs which consists of analysis of total influence. The direct and indirect influence coefficients are listed in the table 10 and 11 below.

Table 10. Direct Effect

\begin{tabular}{|l|l|l|l|l|}
\hline Variable & Belief & Attitude & Subjective Norm & Intention \\
\hline Belief & & 0,326 & & \\
\hline Attitude & & & & 0,277 \\
\hline Subjective Norm & & & & 0,529 \\
\hline Intention & & & & \\
\hline
\end{tabular}


Table 11. Indirect Effect

\begin{tabular}{|l|l|l|l|l|}
\hline Variable & Belief & Attitude & $\begin{array}{l}\text { Subjective } \\
\text { Norm }\end{array}$ & Intention \\
\hline Belief & 1.000 & & 0,216 & 0,208 \\
\hline Attitude & & 1.000 & & 0,325 \\
\hline $\begin{array}{l}\text { Subjective } \\
\text { Norm }\end{array}$ & & & 1.000 & \\
\hline Intention & & & & 1.000 \\
\hline
\end{tabular}

From the direct coefficient data above, it can be seen that from the above variables, the biggest influence is the subjective norm and the smallest influence is the attitude. From these results it can be seen that to bring up the intention to share role knowledge and the influence of subjective norms possessed by individuals is very large in determining the good or bad success of the intention to share knowledge. On the other hand, it can be seen that the role and influence of attitudes are still so small that they can be pursued to be improved.

Whereas based on indirect coefficient data, it is known that from the variable above the attitude variable has a large influence value while the belief variable has a small influence and role.

\section{RESULTS OF DATA ANALYSIS}

\section{Influence of Individual Attitudes Towards Intention to Share Knowledge}

Based on the calculation results obtained structural coefficient value of 0.277 with $t$-value of $2,397>1.98$ and $p$ value of $0.017>0.05$, then the hypothesis which states the influence of individual attitudes towards intention to share is unacceptable so that these factors must be evaluated and assessed reset it.

\section{Influence of Individual Beliefs Towards Intention to Share Knowledge}

Based on the calculation results obtained structural coefficient value of 0.326 with t-value of $4.536>1.98$ and $p$ value of $0.00<0.05$, then the hypothesis which states the influence of individual beliefs on the intention to share knowledge can be accepted. Thus there is a significant influence of individual attitudes towards the intention to share knowledge.

\section{Influence of Subjective Norm Towards Intention to Share Knowledge}

Based on the calculation results obtained structural coefficient value of 0.529 with $\mathrm{t}$-value of $4.966>1.98$ and $p$ value of $0.00<0.05$, then the hypothesis which states the influence of subjective norms on the intention to share knowledge can be accepted. Thus there is a significant influence of subjective norms on the intention to share knowledge.

\section{ANALYSIS OF VARIABLE RESULTS}

\section{Belief Variable}

In the belief variable, the recapitulation of the results of the respondents' responses to perceptions of beliefs has been obtained and the achievement of scores is $75.11 \%$, which means that the trust variable reaches a good category. The question about this variable is "I believe that my friends influence me to share my knowledge"

\section{Attitude Variable}

In this variable, the results of recapitulation of respondents' responses to perceptions of attitudes with a score of $92 \%$ have been obtained which means that this variable reaches a very good category. The question about this variable are "I would like to share my knowledge if there is media available to use", " I loved to search knowledge that my friends already shared", "I loved to share my knowledge if my friends share their knowledge too".

\section{Subjective Norm Variable}

In this variable, the results of the recapitulation of respondents' responses to the perception of subjective norms with a score of $92 \%$, which means that this variable reaches a very good category. The question about this variable are "I will share my knowledge if I get support from my friends", " I will join discussion forum if there is such an interesting topic", "My friends and I share our knowledge oftenly to others".

\section{Intention Variable}

In this variable, the results of recapitulation of respondents' responses to the perception of intention with a score of $94 \%$ have been 
obtained which means that this variable reaches a very good category.

The question about this variable are "I intend to share my knowledge", " I feel no doubt to share my knowledge", "I will share my knowledge if people asked".

\section{REQUIREMENT ANALYSIS}

\section{Functional Requirement}

Specifications for functional requirements are determined based on general needs. Functional requirements are represented by a number of features that will be provided based on the results of the hypothesis. The variable whose hypothesis is rejected, the feature will not be implemented. For a clearer explanation can be seen in table 12.

Table 12. Functional Requirement

\begin{tabular}{|l|l|l|l|l|}
\hline ID & Variable & Feature & Service & Description \\
\hline $\begin{array}{l}\text { F01 } \\
\text { KSS- }\end{array}$ & $\begin{array}{l}\text { Subjective } \\
\text { norm, } \\
\text { intention }\end{array}$ & $\begin{array}{l}\text { Knowledge } \\
\text { sharing } \\
\text { KS }\end{array}$ & $\begin{array}{l}\text { Share } \\
\text { Knowledge }\end{array}$ & $\begin{array}{l}\text { This feature is made to share } \\
\text { documented data }\end{array}$ \\
\hline $\begin{array}{l}\text { KSS- } \\
\text { F03 }\end{array}$ & $\begin{array}{l}\text { Subjective } \\
\text { norm, } \\
\text { Intention }\end{array}$ & $\begin{array}{l}\text { Discussion } \\
\text { forum }\end{array}$ & $\begin{array}{l}\text { Discussion } \\
\text { forum }\end{array}$ & $\begin{array}{l}\text { This feature allows members to } \\
\text { discuss each other on a topic }\end{array}$ \\
\hline $\begin{array}{l}\text { KSS- } \\
\text { F04 }\end{array}$ & $\begin{array}{l}\text { Subjective } \\
\text { norm }\end{array}$ & Comment & Comment & $\begin{array}{l}\text { This features is provided for } \\
\text { commenting } \\
\text { knowledge that has been shared and }\end{array}$ \\
\hline
\end{tabular}

\section{Non Functional Requirement}

The requirement for non-functional is an additional requirement that do not have input and output. However, these non-functional needs should be fulfilled. Non- functional requirements are categorized based on the PIECES frameworks (Performance, Information, Economics, Control, Efficiency, Service). For a clearer explanation can be seen in table 13 .

Table 13. Non Functional Requirement

\begin{tabular}{|l|l|}
\hline \multicolumn{1}{|c|}{$\begin{array}{c}\text { Type of } \\
\text { Requirement }\end{array}$} & \multicolumn{1}{c|}{ Explanation } \\
\hline Performance & Documentation of knowledge can be done quickly \\
\hline Information & $\begin{array}{l}\text { Information that has been shared is in accordance with } \\
\text { personal experience }\end{array}$ \\
\hline Economics & $\begin{array}{l}\text { Reducing costs and time spent by members to share } \\
\text { knowledge }\end{array}$ \\
\hline Control & Data stored and controlled in the database \\
\hline Efficiency & Speed up the process of sharing knowledge \\
\hline Service & Data that has been shared can be read and structured \\
\hline
\end{tabular}

\section{SUMMARY}

Based on the results of the data analysis of research and discussion on the Application of Theory of Reasoned Action (TRA) in the Knowledge Sharing Process between
Alumni and Students of the Information Systems Department (Case Study: Unsri Facilitator), the researcher draws the following conclusions; To bring up the intention in sharing knowledge the role of subjective beliefs and norms of the surrounding environment is very influential so that attitudes can be formed to share. This is because 
the factors of intention, beliefs and subjective norms are factors that play a role in creating attitudes to share.

After doing the calculation, it was found that the attitude variable did not affect someone's intention to share. After analysis and calculation, the researcher managed to get 3 features as a reference prototype, namely; share knowledge, search knowledge and comments.

\section{REFERENCES}

[1] Tobing, P. L., 2007. Knowledge Management; Konsep, Arsitektur dan Implementasi, Graha Ilmu, Yogyakarta.

[2] Orr, E., and Persson, M., 2003. Performance Indicators for Measuring Performance of Activities in Knowledge Management Projects, Master Thesis, Department of Informatics, University of Gothenburg.

[3] Zarzuela, P., \& Anton, C. (2015). Revista Española de Investigación de Marketing ESIC Determinants of social commitment in the young. Applying the Theory of Reasoned Action. Revista Espanola de Investigacion En Marketing ESIC, 19(2),83-94.

[4] Eagle, Lynne, 2013. Social Marketing. Pearson Education: Edinburgh Gate

[5] Abdillah, Willy dan Jogiyanto. 2015. Partial Least Squares - Alternative Structural Equation Modeling (SEM) Dalam Penelitian Bisnis. Yogyakarta: Andi Offset

[6] Ghozali, Imam. 2005. Aplikasi Analisis Multivariate Dengan Program SPSS. Semarang: Badan Penerbit Universitas Diponegoro. 